\title{
About the use of semi-continuity to remove fireproof coatings in simply supported composite steel and concrete beams
}

\section{Sobre o aproveitamento da semicontinuidade para eliminar o revestimento contra fogo em vigas mistas de aço e concreto biapoiadas}
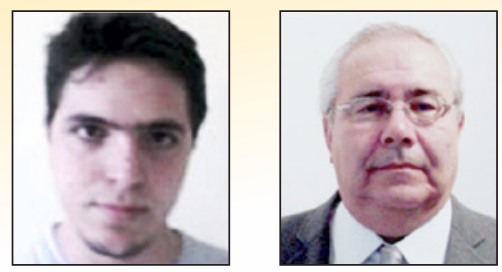

L. C. ROMAGNOLI lucas.romagnoli@usp.br

V. P. SILVA a valpigss@usp.br

\section{Abstract}

The behavior under fire conditions of composite steel and concrete beams, not subjected to local buckling (compact steel profile), was studied considering the support rotational stiffness provided by the upper longitudinal slab reinforcement, usually present by means of anti-cracking meshes, and restriction of the steel profile's lower flange, additional procedure required for development of the support bending moment resistance. Usually composite beams at room temperature are designed as simply supported and the semi-rigidity provided by this longitudinal reinforcement, if considered under fire conditions, may lead to a lower cost solution for fire protection of composite beams. The purpose of this study is to verify the viability of this proposal, using simplified design code methods.

Keywords: fire, composite steel concrete beam, semi-continuous.

\section{Resumo}

Estudou-se o comportamento sob ação do incêndio de vigas mistas de aço e concreto, sem instabilidades locais (ditas compactas), considerando a rigidez à flexão nos apoios fornecida pela armadura negativa longitudinal à viga, usualmente presente por meio de malhas antifissuração, e restrição da mesa inferior do perfil de aço, procedimento adicional necessário para desenvolvimento do momento fletor resistente no apoio. Geralmente as vigas mistas são dimensionadas à temperatura ambiente como biapoiadas e a semicontinuidade proporcionada por essa armadura longitudinal, se considerada em situação de incêndio, pode conduzir a uma solução de menor custo para proteção contra fogo das vigas mistas. O objetivo deste trabalho é verificar a viabilidade dessa proposta, usando métodos normativos simplificados.

Palavras-chave: incêndio, viga mista de aço e concreto, semicontínua.

Escola Politécnica da Universidade de São Paulo, SP, Brasil. 


\section{Introduction}

\subsection{Objective}

A simply supported composite steel and concrete beam designed at room temperature, when analyzed in a fire situation according to ABNT NBR 14323 [1] procedures, generally does not have sufficient structural safety unless fireproof coatings are present. Such solution is responsible for raising costs related to the choice of the composite structural system.

The objective of this study is to evaluate the behavior of composite steel and concrete beams in fire situation, taking in consideration the rotational stiffness of the supports provided by the upper longitudinal reinforcement present in the concrete slab and by the restriction of the steel profile's lower flange in the support, creating a composite connection as shown in Figure 1 and ensuring a semicontinuous behavior to the beam. The beam structural capacity increase provided by the adoption of this solution may be sufficient as a low cost alternative when compared to the application of fireproof coatings. For validity of the proposed method it is assumed that the main supporting beam, connecting plates and angles and bolts receive fireproof coating.

In a steel profile under a concrete slab its faces are not exposed equally by the fire since the slab provides a protection to the upper flange, leading to a non-uniform distribution of the internal temperature. This thermal gradient along the cross section height causes additional deformations and, in case of hyper-static structures, indirect stresses due to the supports rotation restriction. Figure 2 illustrates this phenomenon. If the structure is already subjected to negative bending moments at the support, they may be amplified during fire exposure.

At first, this harmful effect will be neglected in use of a simplified method and evaluated in the future by non-linear thermal structural numerical analysis.

\subsection{Background}

The benefits of composite steel and concrete construction fire resistance in a building, when compared to the isolated steel element analyzed in laboratory, has been the subject of studies by several authors. Based on the Cardington test, where the capacity of the composite structure was verified to be greater in comparison to the design codes recommendations, Usmani et al., 2001 [2, 3], observed the possibility of reducing fireproof coatings for this type of structural system. With aid of numerical analysis it was pointed out that the large deformations caused by the degradation of the steel's elastic modulus are responsible for inducing tension stresses on the steel beam and concrete slab, creating a membrane effect capable of resisting gravitational actions. Recent studies by Kodur et al., [4], show how beneficial it may be to consider such effect on slab panels over beams without fireproof coating, reaching 60 and 90 minute fire resistance times. Huang et al., 2015 [5], emphasize the role of reinforcement steel meshes in the concrete slab to resist membrane stresses. Design code methods do not consider such effect that can be better evaluated with numerical modeling, as concluded by Wang et al., 2012 [6] when comparing numerical analysis results of an asymmetric composite beam without fireproof coating with the Eurocode recommendations.

With consideration of the membrane effect the formation of plastic hinges is no longer the beam ultimate limit state, which explains the large differences between numerical models and design codes recommendations. Chiou et al., 2009 [7], conclude that the axial restriction of the beam is sufficient to mobilize tensile stresses, but alert for large permanent deformations in the floor, which do not recover during the cooling phase. The beam's shear force capacity should also be carefully analyzed because according to Kodur and Naser, 2015 [8], in some cases such capacity can degrade more rapidly compared to the bending moment during fire.

Nguyen and Tan, 2015 [9], point out that boundary conditions play

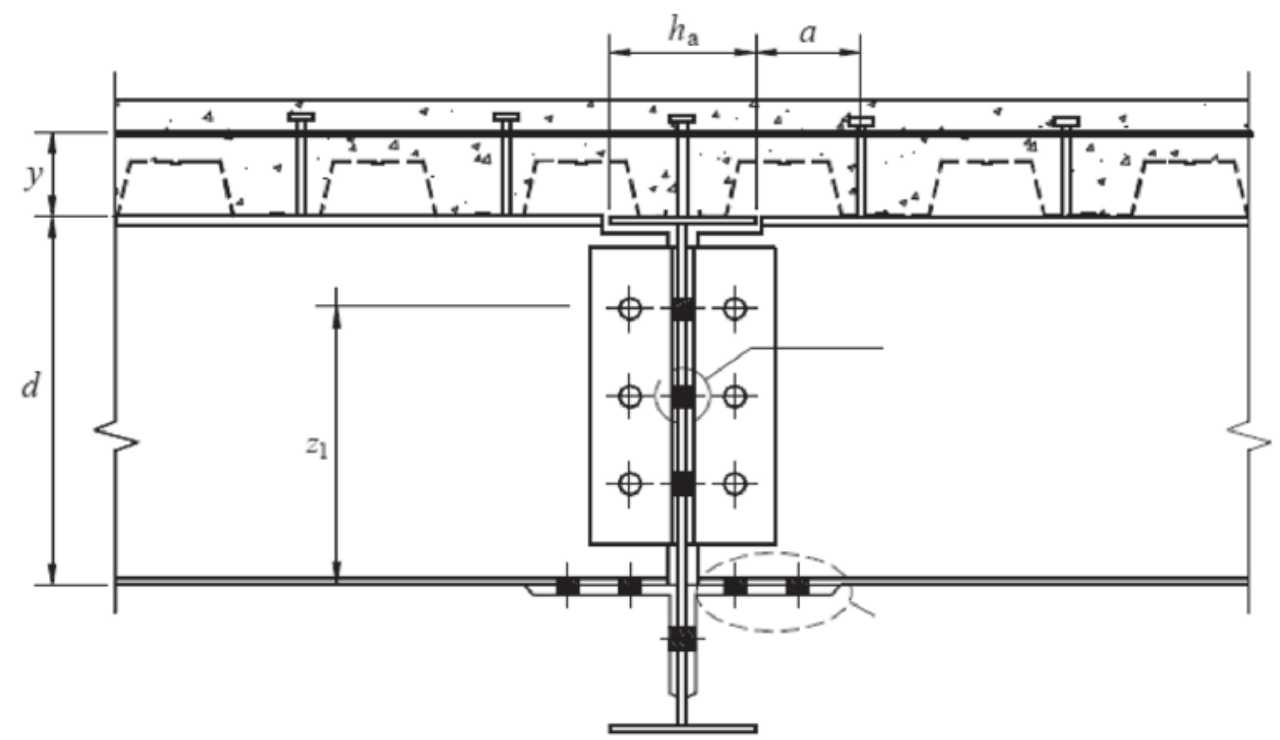

Figure 1

Composite connection (adapted from ABNT NBR 8800 [13]) 

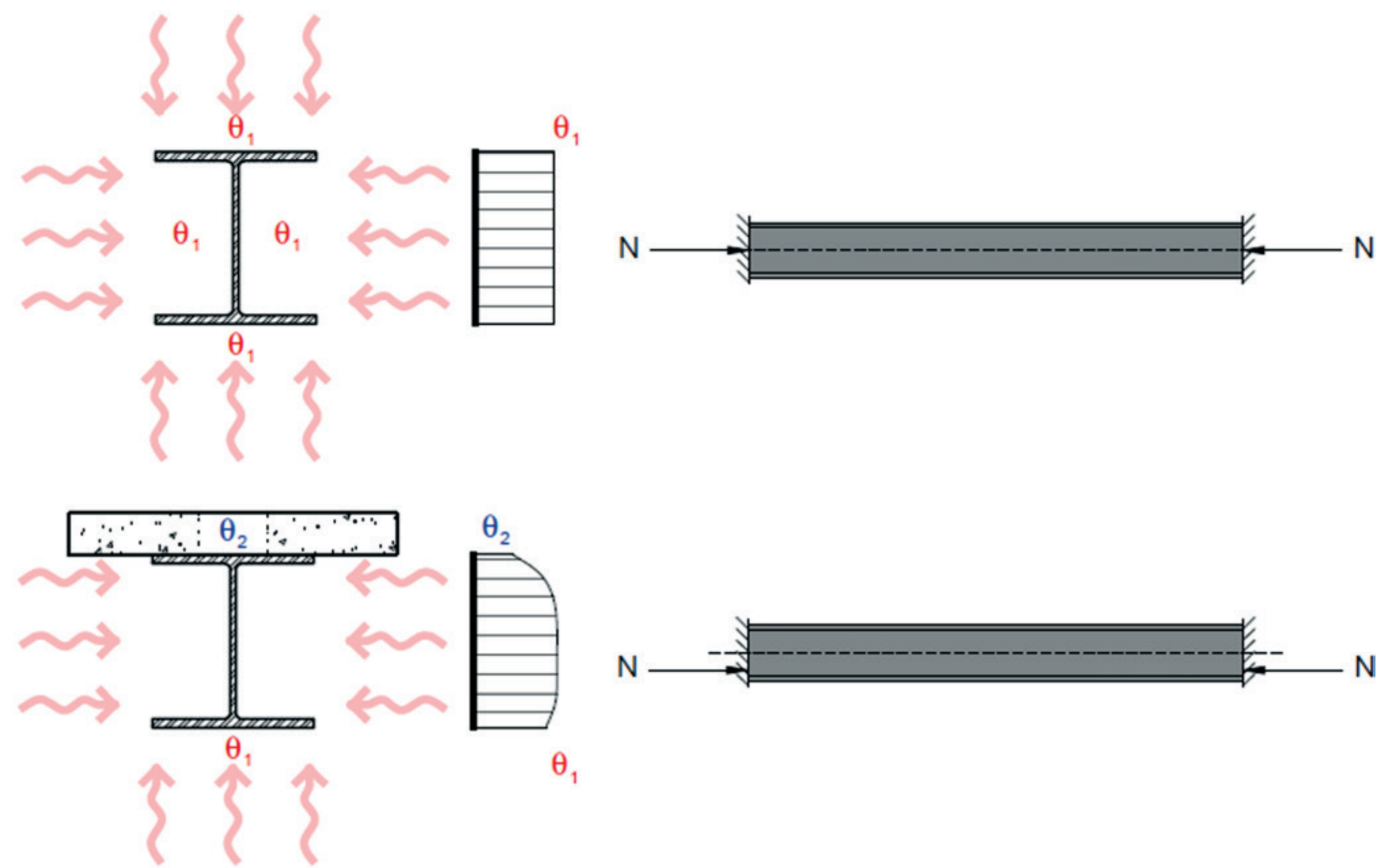

Figure 2

Thermal gradient effects illustration

an important role in the mobilization of the membrane effect, concluding that the stiffness of the fireproof coated main beams supporting the secondary floor beams has a direct influence on the collapse time. Huang et al., 2015 [5] present similar results, also alerting to the influence of the main beam-column connections. The consideration of semicontinuity in the analysis of composite beams in a fire has already been proposed by loannides and Mehta, 1997 [10] who adopted as methodology the determination of the beam's cross section plastic hinge capacity in the middle of the span and at the supports and concluded, in the case of a fireproof coated beam, that there is a relevant gain in its load capacity. Fakury et al., 2005 [11], compared simply supported and semi-continuous fireproof coated composite beams capacities, using the Eurocode design method, and detected a capacity gain of $116 \%$ to $123 \%$. Fischer and Varma, 2017 [12], performed a numerical analysis of fireproof coated composite beams supported by simple shear connections (single plate, single angle and double angle), concluding that the slab continuity at the supports and presence of reinforcement steel meshes have great influence on the behavior of the beam during fire and the collapse did not occur due to connections failure.

\subsection{Problem analysis}

The study was carried for several cross sections, covering the variety of Gerdau brand profiles and 8 to $18 \mathrm{~cm}$ slab thicknesses.
Following the recommendation of ABNT NBR 8800 [13] 0.2.4.1.1, adjusted for fire situation as suggested by ABNT NBR 14323 [1] by reducing slenderness parameters by 0.85 of its room temperature values, some profiles classified as slender, that is, with a flange width and thickness ratio greater than $0,32 \sqrt{\mathrm{E} / \mathrm{f}_{\mathrm{y}}}$, were not considered in the analysis. The compressive strength of the concrete was assumed $30 \mathrm{MPa}$ and the steel yield strength $345 \mathrm{MPa}$.

The distortional buckling that may occur in the negative bending moment regions of composite beams was not considered. Therefore, for direct use of the presented results, it must be ensured that the $\lambda_{\text {dist }}$ parameter, determined according to ABNT NBR 8800 [13] O.2.5.2, is higher than 0.4. ABNT NBR 14323 [1] does not provide specific recommendations for distortional buckling of composite beams in fire, but in case of cold formed profiles it is advised $\lambda_{\text {dist }}$ to be calculated as at room temperature, however with a more severe high temperature steel's reduction factor than the one used in profiles not subjected to local or distortional buckling. Such factor is found in [1].

The effective width of the concrete slab was $2 \mathrm{~m}$ for all cases. The slab reinforcement ratio was such that it allowed the development of the maximum negative bending moment resistance, as explained in chapter 5 . The number of shear connectors was the required for full iteration at room temperature.

The fire resistant strength of the beams was evaluated, assuming a standard fire resistance requirement of 30 minutes for the 
simply supported and semi-continuous condition, and the values were compared to those at room temperature design.

The standard fire resistance requirement of $30 \mathrm{~min}$ was chosen because it is a low value and, therefore, more likely to lead to favorable results.

\section{Structural elements temperature}

In the calculation of the resistant capacity of composite steel and concrete sections a non-uniform temperature distribution at the height of the cross-section is considered. The recommendation of ABNT NBR 14323 [1] is to divide the composite section into each of its components: the concrete slab and the steel profile upper and lower flanges and web. It is assumed that there is no heat transfer between these parts.

In the steel elements, the temperature increase of each component is determined considering the massivity factor calculated for each element alone, according to the simplified method recommended by ABNT NBR 14323 [1] 8.5.1.1. In security favor, the shading factor will be considered equal to 1 , following one of $A B N T$ NBR 14323 [1] alternatives.

To evaluate the temperature at which the composite beam concrete slab is subjected during fire, the recommendation of ABNT NBR 14323 [1] is to divide the height of the slab in 14 slices and assign a temperature for each range according to the standard fire resistance requirement (Table 1 ).

\section{Shear connectors}

ABNT NBR 14323 [1] recommends the strength of a shear connector to be determined in the same way as ABNT NBR 8800 [13], taking into consideration, however, reduction factors of unity and concrete compressive strength and elastic modulus reduced by $k_{c, \theta}$ at a temperature equivalent to $40 \%$ of the steel profile upper flange temperature. The shear connector ultimate tensile strength should also be reduced by $0.80 k_{y, \theta}$ for a temperature equivalent to $80 \%$ of the temperature of the steel profile upper flange.

Equation (1) is already adjusted for fire situation.

$Q_{f i, R d}=\operatorname{mí}\left\{\begin{array}{l}0,50 A_{c s} k_{c, \theta} \sqrt{f_{c k} E_{c s}} \\ 0,80 k_{y, \theta} R_{g} R_{p} A_{c s} f_{u c s}\end{array}\right.$

In Equation (1):

$Q_{\mathrm{fi}, R d}$ is the shear connector strength in fire situation;

$A_{c s}$ is the shear connector cross-section area;

$\mathrm{k}_{\mathrm{c}, \theta}$ is the concrete reduction factor;

$\mathrm{k}_{\mathrm{y}, \theta}$ is the steel reduction factor;

$f_{c k}$ is the concrete compressive strength;

$\mathrm{f}_{\text {ucs }}$ is the steel ultimate tensile strength;

$\mathrm{E}_{\mathrm{cs}}$ is the concrete elastic modulus;

$R_{g}$ is the factor used for consideration of a group of shear connectors;

$R_{p}$ is the factor used for consideration of shear connector position.

\section{Positive bending moment resistance}

The design procedure described by ABNT NBR 14323 [1] is limited to recommendations of using the room temperature design suggested by ABNT NBR 8800 [13] with reduction factors of unity and reducing the concrete compressive strength and steel yield strength by $\mathrm{k}_{\mathrm{c}, \theta}$ and $\mathrm{k}_{\mathrm{y}, \theta}$ coefficients, respectively.

The factor of 0.85 used to determine the maximum compressive stress in the concrete slab will be assumed as 1.00 according to the recommendation of Bulletin $n^{\circ} 46$ fib-CEB, 2008 [14].

\section{Table 1}

Concrete slab temperature distribution [ ${ }^{\circ} \mathrm{C}$ ] (adapted from ABNT NBR 14323 [1] and EN 1994-1-2 [15])

\begin{tabular}{|c|c|c|c|c|c|c|c|}
\hline \multirow{2}{*}{ Slice } & Height & \multicolumn{7}{|c|}{ Standard fire resistance requirement (min) } \\
\cline { 3 - 9 } & (y) $\mathbf{m m}$ & $\mathbf{3 0}$ & $\mathbf{6 0}$ & $\mathbf{9 0}$ & $\mathbf{1 2 0}$ & $\mathbf{1 8 0}$ & $\mathbf{2 4 0}$ \\
\hline 1 & 0 a 5 & 535 & 705 & - & - & - & - \\
\hline 2 & 5 a 10 & 470 & 642 & 738 & - & - & - \\
\hline 3 & 10 a 15 & 415 & 581 & 681 & 754 & - & - \\
\hline 4 & 15 a 20 & 350 & 525 & 627 & 697 & - & - \\
\hline 5 & 20 a 25 & 300 & 469 & 571 & 642 & 738 & - \\
\hline 6 & 25 a 30 & 250 & 421 & 519 & 591 & 689 & 740 \\
\hline 7 & 30 a 35 & 210 & 374 & 473 & 542 & 635 & 700 \\
\hline 8 & 35 a 40 & 180 & 327 & 428 & 493 & 590 & 670 \\
\hline 9 & 40 a 45 & 160 & 289 & 387 & 454 & 549 & 645 \\
\hline 10 & 45 a 50 & 140 & 250 & 345 & 415 & 508 & 550 \\
\hline 11 & 50 a 55 & 125 & 200 & 294 & 369 & 469 & 520 \\
\hline 12 & 55 a 60 & 110 & 175 & 271 & 342 & 430 & 495 \\
\hline 14 & 60 a 80 & 80 & 140 & 220 & 270 & 330 & 395 \\
\hline
\end{tabular}


Given a standard fire resistance requirement, the maximum allowable compressive force in the concrete slab is determined as the sum of the plastic forces of each temperature slice (Table 1) multiplied by $\mathrm{k}_{\mathrm{c}, \theta}$ factor, according to Equation (2).

$C_{c d, f i}^{m a ́ x}=b f_{c k} \sum h^{n} k_{c, \theta}^{n}$

In Equation (2):

$b$ is the slab effective width;

$\mathrm{h}^{\mathrm{n}}$ is the thickness of the $\mathrm{n}^{\text {th }}$ slab slice;

$\mathrm{k}_{c, \theta}^{\mathrm{n}}$ is the reduction factor of the $\mathrm{n}^{\text {th }}$ slab slice.

The maximum tensile strength which the steel profile can be subjected is the sum of the plastic forces of each element (lower flange, web and upper flange), according to Equation (3).

$T_{a d, f i}^{m a ́ x}=f_{y}\left(A_{w} k_{y, \theta}^{w}+A_{f s} k_{y, \theta}^{f s}+A_{f i} k_{y, \theta}^{f i}\right)$

The index "w" corresponds to the steel profile web, the index "fs" to the upper flange and "fi" to the lower flange.

When the sum of the resistances in fire situation of the shear connectors located between the section of maximum positive bending moment and the adjacent null bending moment section

$\sum Q_{f i, R d}$ is greater than the lower of the values $T_{a d, f i}^{\text {máx }}$ and $C_{c d, f i}^{m a x}$ a full interaction is characterized, for lower values a partial interaction is characterized.

\subsection{Plastic neutral axis on concrete slab}

In a full interaction, when $C_{c d, f i}^{m a x} \geq T_{a d, f i}^{m a ́}$, the plastic neutral axis must be, by equilibrium, in the concrete slab. Thus, the tensile force in the steel profile is given by Equation (4).

$T_{a d, f i}=T_{a d, f i}^{m a ́ x}$

The amount of slab slices to be considered should be such that

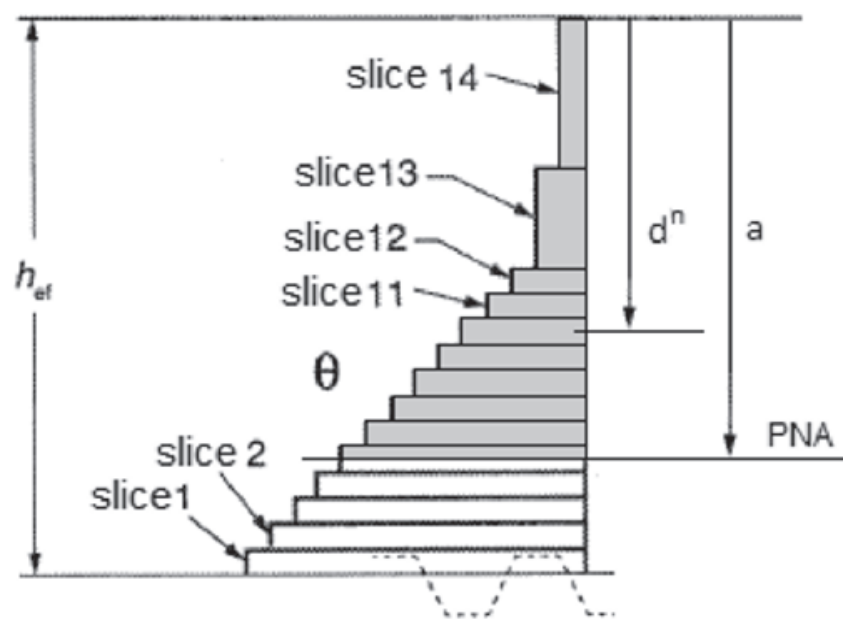

Figure 3

Slab height under compression "a" (adapted from ABNT NBR 14323 [1]) the compressive force $C_{c d, f i}$ is equal to $T_{a d, f i}$, for this the value of a (Figure 3), starting from the top of the slab, that satisfies the $\mathrm{C}_{\mathrm{cd}, \mathrm{fi}}=\mathrm{T}_{\mathrm{ad}, \mathrm{fi}}$ condition must be found.

The bending moment resistance must be determined by multiplying the plastic forces of each element (lower and upper flanges, web and slab slices) by the C.G. distance of each element to the PNA. Equations (5) to (8) indicate the contribution of each element (parameters according to Figure 4).

$M_{f i, R d}^{f s}=f_{y} A_{f s} k_{y, \theta}^{f s}\left(\frac{t_{f s}}{2}+h_{F}+t_{c}-a\right)$

$M_{f i, R d}^{w}=f_{y} A{ }_{w} k_{y, \theta}^{w}\left(\frac{h_{w}}{2}+t_{f s}+h_{F}+t_{c}-a\right)$

$M_{f i, R d}^{f i}=f_{y} A_{f i} k_{y, \theta}^{f i}\left(\frac{t_{f i}}{2}+h_{w}+t_{f s}+h_{F}+t_{c}-a\right)$

$M_{f i, R d}^{c}=b f_{c k} \sum h^{n} k_{c, \theta}^{n}\left(a-d^{n}\right)$

The $d_{n}$ parameter represents the distance from the C.G. of each slab slice under compression to the upper face of the slab, according to Figure 3.

The bending moment resistance in fire situation is then defined by Equation (9).

$M_{f i, R d}=M_{f i, R d}^{c}+M_{f i, R d}^{f s}+M_{f i, R d}^{w}+M_{f i, R d}^{f i}$

\subsection{Plastic neutral axis on steel profile}

In full interaction, when $T_{a d, f i}^{m a ́ x}>C_{c d, f i}^{m a ́ x}$ the plastic neutral axis is found on the steel profile. The compressive force in the concrete slab is given by Equation (10).

$C_{c d, f i}=C_{c d, f i}^{m a ́ x}$

The compression force $\mathrm{C}_{\mathrm{ad}, \mathrm{fi}}$ on the steel profile is given by Equation (11) in order to balance the tensile and compression forces in the cross section.

$C_{a d, f i}=\frac{1}{2}\left(T_{a d, f i}^{m a ́ x}-C_{c d, f i}\right)$

If the compression force in the steel profile is lower than the plastic

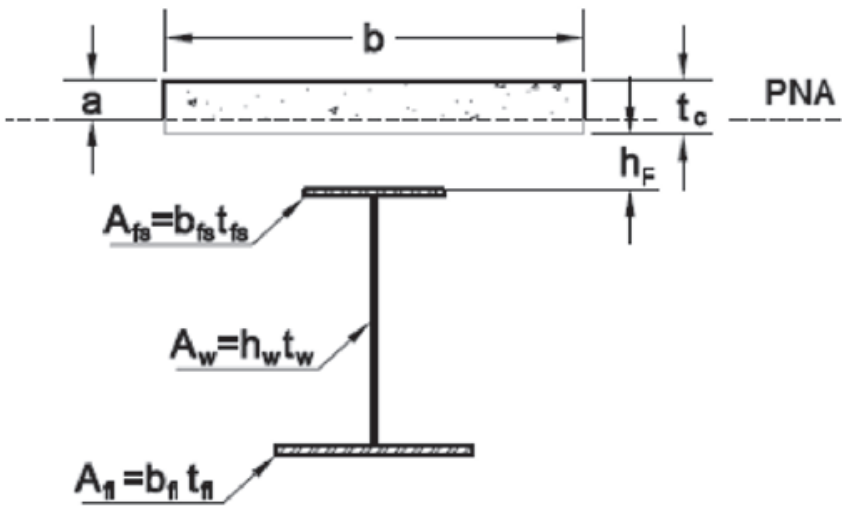

Figure 4

Plastic neutral axis on concrete slab 
force of the upper flange, that is $C_{a d, f i} \leq f_{y} A_{f s} k_{y, \theta}^{f s}$, the PNA is located on the upper flange and its position relative to the upper face of the steel profile $y_{p}$ is defined by Equation (12).

$y_{p}=\frac{C_{a d, f i}}{f_{y} A_{f s} k_{y, \theta}^{f s}} t_{f s}$

Equations (13) to (16) indicate the contribution of each element for the bending moment resistance, relative to the PNA. Figure 5 illustrates the position of the plastic neutral axis.

$M_{f i, R d}^{f s}=\frac{f_{y} A_{f s} k_{y, \theta}^{f s}}{2 t_{f s}}\left[y_{p}{ }^{2}+\left(t_{f s}-y_{p}\right)^{2}\right]$

$M_{f i, R d}^{w}=f_{y} A{ }_{w} k_{y, \theta}^{w}\left(\frac{h_{w}}{2}+t_{f s}-y_{p}\right)$

$M_{f i, R d}^{f i}=f_{y} A_{f i} k_{y, \theta}^{f i}\left(\frac{t_{f i}}{2}+h_{w}+t_{f s}-y_{p}\right)$

$M_{f i, R d}^{c}=b f_{c k} \sum h^{n} k_{c, \theta}^{n}\left(t_{c}+h_{F}+y_{p}-d^{n}\right)$

The $\mathrm{d}^{\mathrm{n}}$ parameter represents the distance from the C.G. of each slice under compression to the upper face of the slab, according to Figure 3.

If $C_{a d, f i}>f_{y} A_{f s} k_{y, \theta}^{f s}$ the plastic neutral axis is located in the steel profile web and its position relative to the upper face of the steel profile is given by Equation (17).

$y_{p}=t_{f s}+h_{w}\left(\frac{C_{a d, f i}-A_{f s} f_{y} k_{y, \theta}^{f s}}{A_{w} f_{y} k_{y, \theta}^{w}}\right)$

Equations (18) to (21) indicate the contribution of each element for the bending moment resistance, relative to the PNA.

Figure 6 shows the position of the plastic neutral axis.

$M_{f i, R d}^{f s}=f_{y} A_{f s} k_{y, \theta}^{f s}\left(y_{p}-\frac{t_{f s}}{2}\right)$

$M_{f i, R d}^{w}=\frac{f_{y} A_{w} k_{y, \theta}^{w}}{2 h_{w}}\left[\left(y_{p}-t_{f s}\right)^{2}+\left(h_{w}+t_{f s}-y_{p}\right)^{2}\right]$

$M_{f i, R d}^{f i}=f_{y} A_{f i} k_{y, \theta}^{f i}\left(\frac{t_{f i}}{2}+h_{w}+t_{f s}-y_{p}\right)$

$M_{f i, R d}^{c}=b f_{c k} \sum h^{n} k_{c, \theta}^{n}\left(t_{c}+h_{F}+y_{p}-d^{n}\right)$

The bending moment resistance in fire situation is defined as the sum of each element contribution, according to Equation (9).

\subsection{Partial interaction}

In case of a partial interaction it is assumed that the greatest compressive force that can be transmitted to the concrete slab will be the maximum strength of the shear connectors, which is described by Equation (22).

$C_{c d, f i}=\Sigma Q_{f i, R d}$
For this reason, the concrete slab is not entirely under compression, the parameter a (Figure 3, although the value will not correspond to the PNA position) is such that the sum of the slices forces corresponds to $\Sigma_{\text {Qfi, Rd }}$.

Because it is a partial interaction, the strength of the shear connectors is lower than the maximum tensile force which the steel profile can be subjected to, in other words $C_{c d, f i}<T_{a d, f i}^{m a}$, characterizing the same expressions of $C_{a d f i}$ and $y_{p}$ defined in 4.2, but the contribution to the bending moment resistance of the concrete slab $M_{f i, R d}^{c}$ will correspond only to the slices within the compression range $a$.

\section{Table 2}

Calculation parameters

\begin{tabular}{|c|c|c|c|}
\hline$h$ & $313 \mathrm{~mm}$ & $b$ & $2000 \mathrm{~mm}$ \\
\hline$t_{w}$ & $6.6 \mathrm{~mm}$ & $\mathrm{t}_{c}$ & $180 \mathrm{~mm}$ \\
\hline $\mathrm{b}_{\mathrm{f}}$ & $102 \mathrm{~mm}$ & $\mathrm{~h}_{\mathrm{f}}$ & $0 \mathrm{~mm}$ \\
\hline $\mathrm{t}_{\mathrm{f}}$ & $10.8 \mathrm{~mm}$ & $\mathrm{f}_{c k}$ & $30 \mathrm{MPa}$ \\
\hline $\mathrm{f}_{y}$ & $345 \mathrm{MPa}$ & $\begin{array}{c}\text { Standard } \\
\text { fire } \\
\text { resistance } \\
\text { requirement }\end{array}$ & $30 \mathrm{~min}$ \\
\hline
\end{tabular}

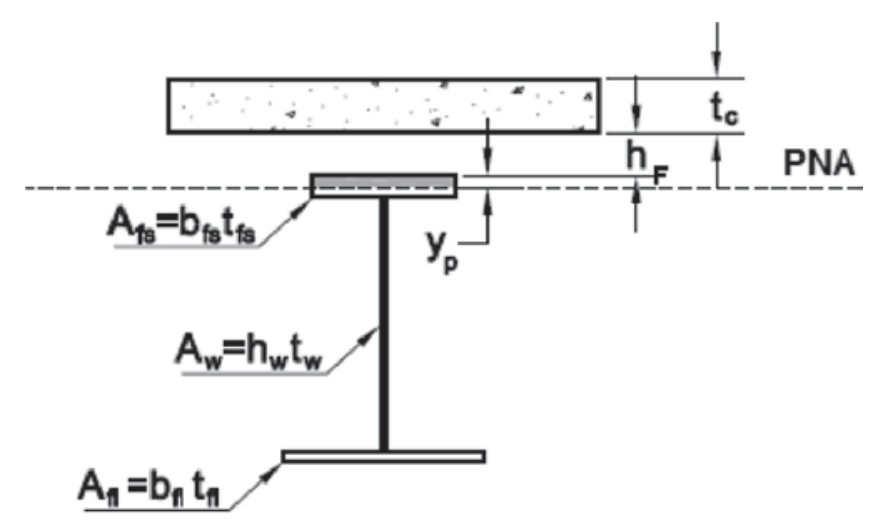

Figure 5

Plastic neutral axis on steel profile upper flange

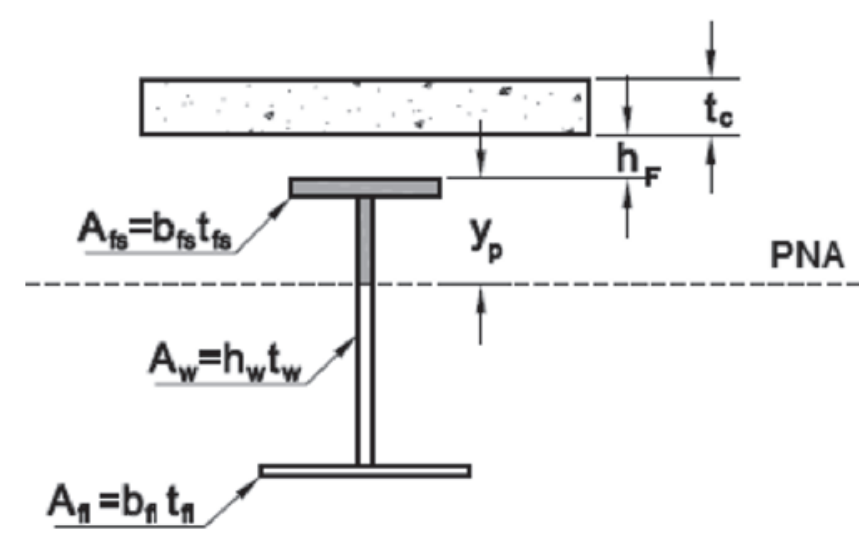

Figure 6

Plastic neutral axis on steel profile web 


\subsection{Design example}

The parameters described in Table 2 represent the design of a W310x32.7 Gerdau profile under a $18 \mathrm{~cm}$ concrete slab, other pa-

\section{Table 3}

Steel elements temperature and reduction factor

\begin{tabular}{|c|c|c|c|}
\cline { 2 - 4 } \multicolumn{1}{c|}{} & $\begin{array}{c}\text { Lower } \\
\text { flange }\end{array}$ & $\begin{array}{c}\text { Upper } \\
\text { flange }\end{array}$ & Web \\
\hline $\mathrm{F}$ & $204.8 \mathrm{~m}^{-1}$ & $112.2 \mathrm{~m}^{-1}$ & $303.0 \mathrm{~m}^{-1}$ \\
\hline$\theta$ & $834^{\circ} \mathrm{C}$ & $824^{\circ} \mathrm{C}$ & $837^{\circ} \mathrm{C}$ \\
\hline $\mathrm{k}_{\mathrm{y}, \theta}$ & 0.09 & 0.10 & 0.09 \\
\hline
\end{tabular}

\section{Table 4}

Concrete slab temperature and reduction factor

\begin{tabular}{|c|c|c|c|}
\hline Slice & $\mathbf{h}$ & $\theta$ & $\mathbf{k}_{\mathrm{c}, \theta}$ \\
\hline 1 & $100 \mathrm{~mm}$ & 60 & 1.00 \\
\hline 2 & $20 \mathrm{~mm}$ & 80 & 1.00 \\
\hline 3 & $5 \mathrm{~mm}$ & 110 & 1.00 \\
\hline 4 & $5 \mathrm{~mm}$ & 125 & 0.99 \\
\hline 5 & $5 \mathrm{~mm}$ & 140 & 0.98 \\
\hline 6 & $5 \mathrm{~mm}$ & 160 & 0.97 \\
\hline 7 & $5 \mathrm{~mm}$ & 180 & 0.96 \\
\hline 8 & $5 \mathrm{~mm}$ & 210 & 0.94 \\
\hline 9 & $5 \mathrm{~mm}$ & 250 & 0.90 \\
\hline 10 & $5 \mathrm{~mm}$ & 300 & 0.85 \\
\hline 11 & $5 \mathrm{~mm}$ & 350 & 0.80 \\
\hline 12 & $5 \mathrm{~mm}$ & 415 & 0.73 \\
\hline 13 & $5 \mathrm{~mm}$ & 470 & 0.65 \\
\hline 14 & $5 \mathrm{~mm}$ & 535 & 0.55 \\
\hline
\end{tabular}

\section{Table 5}

Partial results for positive bending moment resistance

\begin{tabular}{|c|c|}
\hline$C_{c d, f i}^{m a ́ x}$ & $10290.8 \mathrm{kN}$ \\
\hline$T_{a d, f i}^{m a x x}$ & $133.4 \mathrm{kN}$ \\
\hline$a$ & $0.22 \mathrm{~cm}$ \\
\hline$M_{f i, R d}^{c}$ & $14.8 \mathrm{kN} . \mathrm{cm}$ \\
\hline$M_{f i, R d}^{f s}$ & $682.2 \mathrm{kN} . \mathrm{cm}$ \\
\hline$M_{f i, R d}^{w}$ & $2032.3 \mathrm{kN} . \mathrm{cm}$ \\
\hline$M_{f i, R d}^{f i}$ & $1717.0 \mathrm{kN} . \mathrm{cm}$ \\
\hline
\end{tabular}

\begin{tabular}{|l|l|}
\hline$M_{\boldsymbol{f i}, \boldsymbol{R} \boldsymbol{d}}$ & $44.5 \mathrm{kN} . \mathrm{m}$ \\
\hline
\end{tabular}

rameters are described in 1.3. The calculation of the temperature in each structural element is summarized in Table 3 and Table 4.

Table 5 indicates other partial results. Note that for this case the plastic neutral axis is located on the concrete slab.

\section{Negative bending moment resistance}

ABNT NBR 14323 [1] suggests to neglecting the concrete slab and the longitudinal reinforcement present in the effective width in sections under negative bending moment, resisting only the steel profile cross section and, of course, resulting in very conservative resistance values. In order to evaluate the effect of the longitudinal reinforcement on the slab near the supports this suggestion will not be followed, and the negative bending moment resistance will be determined according to the general recommendation of EN-19941-2 [15], by plasticity theory taking into account the variation of the materials properties by temperature.

ABNT NBR 15200 [16] defines reduction factors lower than 1.00 for CA-50 steel only for temperatures above $400{ }^{\circ} \mathrm{C}$ and, noting Table 1, the upper slices of the concrete slab do not reach that temperature. It is concluded that the reinforcement located near the top layer of the concrete slab does not suffer a reduction of its capacity even for high values of standard fire resistance requirement; in this way the maximum tensile strength allowed in the negative longitudinal reinforcement within the effective width will be the same as in room temperature, determined by Equation (23).

$T_{d s}=A_{s l} f_{s d}$

At Equation (23):

$A_{s \mid}$ is the total cross sectional area of longitudinal reinforcement within the slab effective width;

$\mathrm{f}_{\text {sd }}$ is the reinforcement steel design yield strength at room temperature. If the reinforcement ratio is too high resulting in $T_{d s} \geq T_{a d, f i}^{m a}$, the entire steel profile will be compressed and the bending moment resistance will be the result from the force couple of the reinforcement and the steel profile. In this case, to ensure that the following formulations do not result in negative values, assume $T_{d s}=T_{a d, f i}^{m a}$. The tensile strength of the steel profile $T_{a d, f i}$ is given by Equation (24) in order to balance the tensile and compression forces in the cross section.

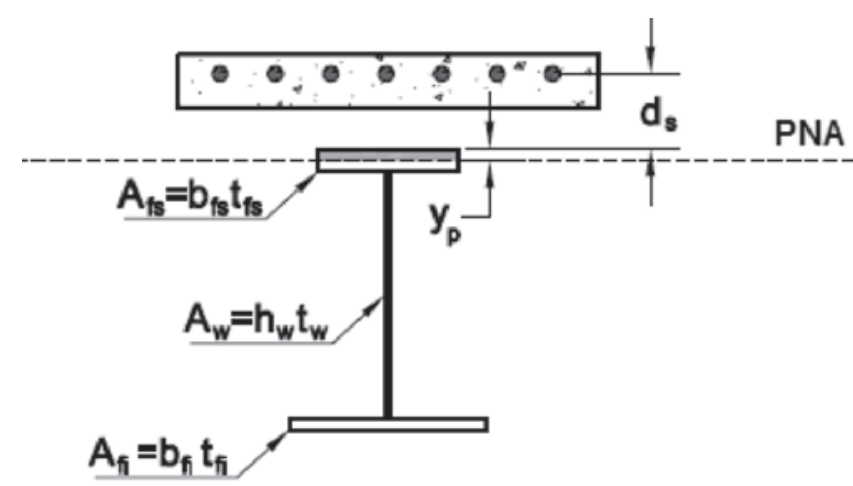

Figure 7

Plastic neutral axis on steel profile upper flange, negative bending moment 
$T_{a d, f i}=\frac{1}{2}\left(T_{a d, f i}^{m a ́ x}-T_{d s}\right)$

If the tensile force in the steel profile is lower than the plastic force of the upper flange, that is $T_{a d, f i} \leq f_{y} A_{f s} k_{y, \theta}^{f s}$, the PNA is located on the upper flange and its position relative to the upper face of the steel profile $y$ is defined by Equation (25).

$y_{p}=\frac{T_{a d, f i}}{f_{y} A_{f s} k_{y, \theta}^{f s}} t_{f s}$

Equations (26) to (29) indicate the contribution for the bending moment resistance of each element, relative to the PNA.

Figure 7 shows the position of the plastic neutral axis.

$M_{f i, R d}^{f s}=\frac{f_{y} A_{f s} k_{y, \theta}^{f s}}{2 t_{f s}}\left[y_{p}{ }^{2}+\left(t_{f s}-y_{p}\right)^{2}\right]$

$M_{f i, R d}^{w}=f_{y} A_{w} k_{y, \theta}^{w}\left(\frac{h_{w}}{2}+t_{f s}-y_{p}\right)$

$M_{f i, R d}^{f i}=f_{y} A_{f i} k_{y, \theta}^{f i}\left(\frac{t_{f i}}{2}+h_{w}+t_{f s}-y_{p}\right)$

$M_{f i, R d}^{s l}=T_{d s}\left(d_{s}+y_{p}\right)$

If $T_{a d, f i}>f_{y} A_{f s} k_{y, \theta}^{f s}$ the plastic neutral axis is located in the steel profile web and its position relative to the upper face of the steel profile is given by Equation (30).

$y_{p}=t_{f s}+h_{w}\left(\frac{T_{a d, f i}-A_{f s} f_{y} k_{y, \theta}^{f s}}{A_{w} f_{y} k_{y, \theta}^{w}}\right)$

Equations (31) to (34) indicate the contribution for the bending moment resistance of each element, relative to the PNA.

Figure 8 shows the position of the plastic neutral axis.

$M_{f i, R d}^{f s}=f_{y} A_{f s} k_{y, \theta}^{f s}\left(y_{p}-\frac{t_{f s}}{2}\right)$

$M_{f i, R d}^{w}=\frac{f_{y} A_{w} k_{y, \theta}^{w}}{2 h_{w}}\left[\left(y_{p}-t_{f s}\right)^{2}+\left(h_{w}+t_{f s}-y_{p}\right)^{2}\right]$

$M_{f i, R d}^{f i}=f_{y} A_{f i} k_{y, \theta}^{f i}\left(\frac{t_{f i}}{2}+h_{w}+t_{f s}-y_{p}\right)$

$M_{f i, R d}^{s l}=T_{d s}\left(d_{s}+y_{p}\right)$

The bending moment resistance in fire situation is defined as the sum of each element contribution, according to Equation (35).

$M_{f i, R d}=M_{f i, R d}^{s l}+M_{f i, R d}^{f s}+M_{f i, R d}^{w}+M_{f i, R d}^{f i}$

\subsection{Design example}

Using the parameters already presented in Table 2 and assuming a reinforcement ratio such that $T_{d s}=T_{a d, f i}^{m a}$, CA-50 reinforcement steel and the distance $d_{s}$ of $15.0 \mathrm{~cm}$, the partial results are presented in Table 6.
Table 6

Partial results for negative bending moment resistance

\begin{tabular}{|c|c|}
\hline$A_{s l}$ & $2.7 \mathrm{~cm}^{2}$ \\
\hline$T_{d s}$ & $133.4 \mathrm{kN}$ \\
\hline$y_{p}$ & $0 \mathrm{~cm}$ \\
\hline$M_{f i, R d}^{s l}$ & $2001.2 \mathrm{kN} . \mathrm{cm}$ \\
\hline$M_{f i, R d}^{f s}$ & $20.1 \mathrm{kN} . \mathrm{cm}$ \\
\hline$M_{f i, R d}^{w}$ & $951.5 \mathrm{kN} . \mathrm{cm}$ \\
\hline$M_{f i, R d}^{f i}$ & $1088.1 \mathrm{kN} . \mathrm{cm}$ \\
\hline
\end{tabular}

\section{$M_{f i, R d}$}

40.6 kN.m

\section{Beam plastic capacity}

It is known from the plastic analysis of a fixed beam that the maximum value of the bending moment in the center of the span will be equal to the cross section positive plastification moment and, in the supports, equal to the cross section negative plastification moment. To achieve equilibrium the sum of these two bending moments must be equal to $\mathrm{pL}^{2} / 8$.

The maximum distributed load to which the beam can be subjected, before the formation of the plastic hinges in the support and center span, is described by Equation (36);

$p_{\text {máx }}=\left(M_{R d}^{+}+M_{R d}^{-}\right) \frac{8}{L^{2}}$

The plastic capacity of the semi-continuous composite beam in fire situation was evaluated by comparing the distributed load in the occurrence of the ultimate limit state, for a 30 min standard fire resistance requirement $\left(p_{f i, 30}\right)$, with the distributed load in the occurrence of the ultimate limit state of the same beam at room temperature, designed as simply supported $\left(p_{0}\right)$. The load factor is

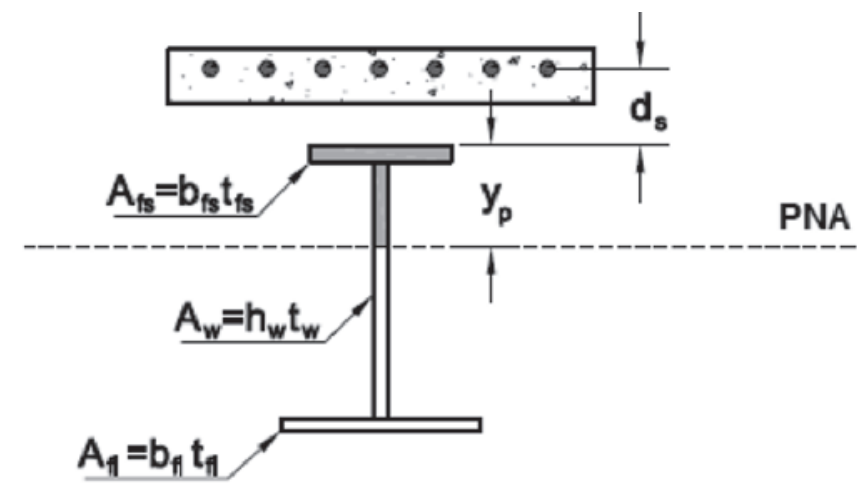

Figure 8

Plastic neutral axis on steel profile web, negative bending moment 
defined here as the ratio between these two values, according to Equation (37).

load factor $=\frac{p_{f i, 30}}{p_{0}}$

Since the span is the same in both cases, the load factor of the semi-continuous composite beam is described, as a function of the bending moments, by Equation (38). In the case of a simply supported composite beam there is no contribution of the negative bending moment resistance.

load factor $=\frac{M_{R d, f i 30}^{+}+M_{R d, f i 30}^{-}}{M_{R d, 0}^{+}}$

\section{Results}

The following graphs indicate the results in the determination of the beam's fire load capacity, admitting a standard fire resistance requirement of $30 \mathrm{~min}$, of composite beams formed by Gerdau steel profiles, ranging from lighter to heavier, and the concrete slab thickness $\left(t_{c}\right)$ ranging from 8 to $18 \mathrm{~cm}$. For each profile (x-axis) a point was generated on the graph, these being connected by a line for easier visualization.

Figure 9 indicates the reinforcement ratios required for the development of the highest possible negative bending moment in the supports, varying the concrete slab thickness $\left(t_{c}\right)$ for the Gerdau profiles W200 series. Figure 10 covers the results for other series of Gerdau profiles. The following results follow the same format; markers were removed for better visualization.

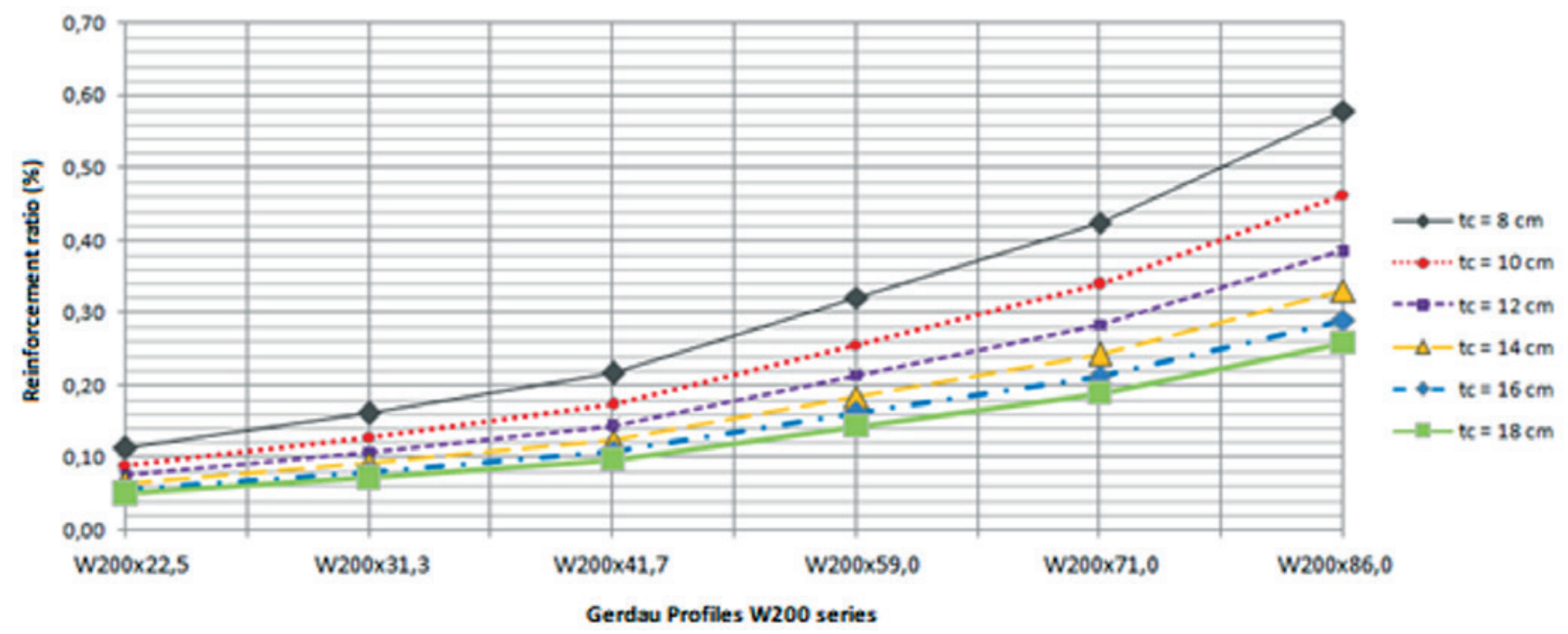

Figure 9

Reinforcement ratio $x$ analyzed Gerdau profile, W200 series
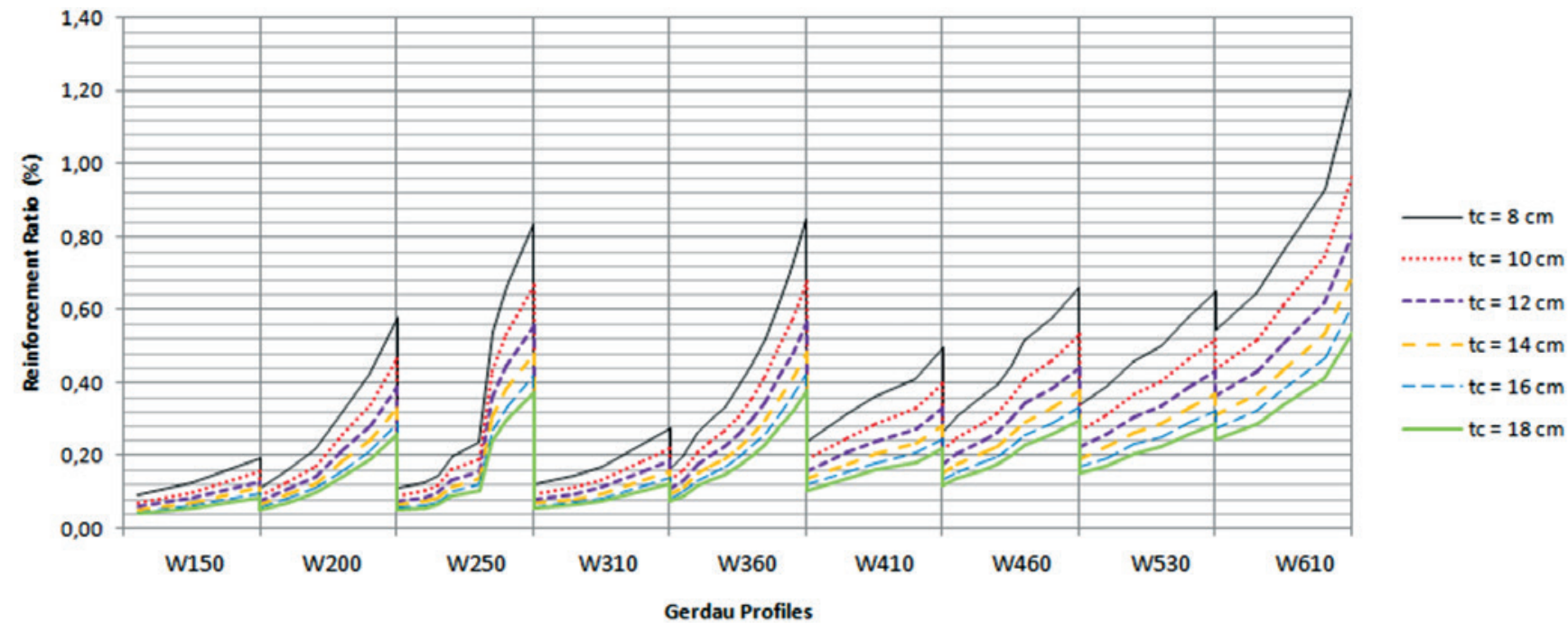

Figure 10

Reinforcement ratio x analyzed Gerdau profile 


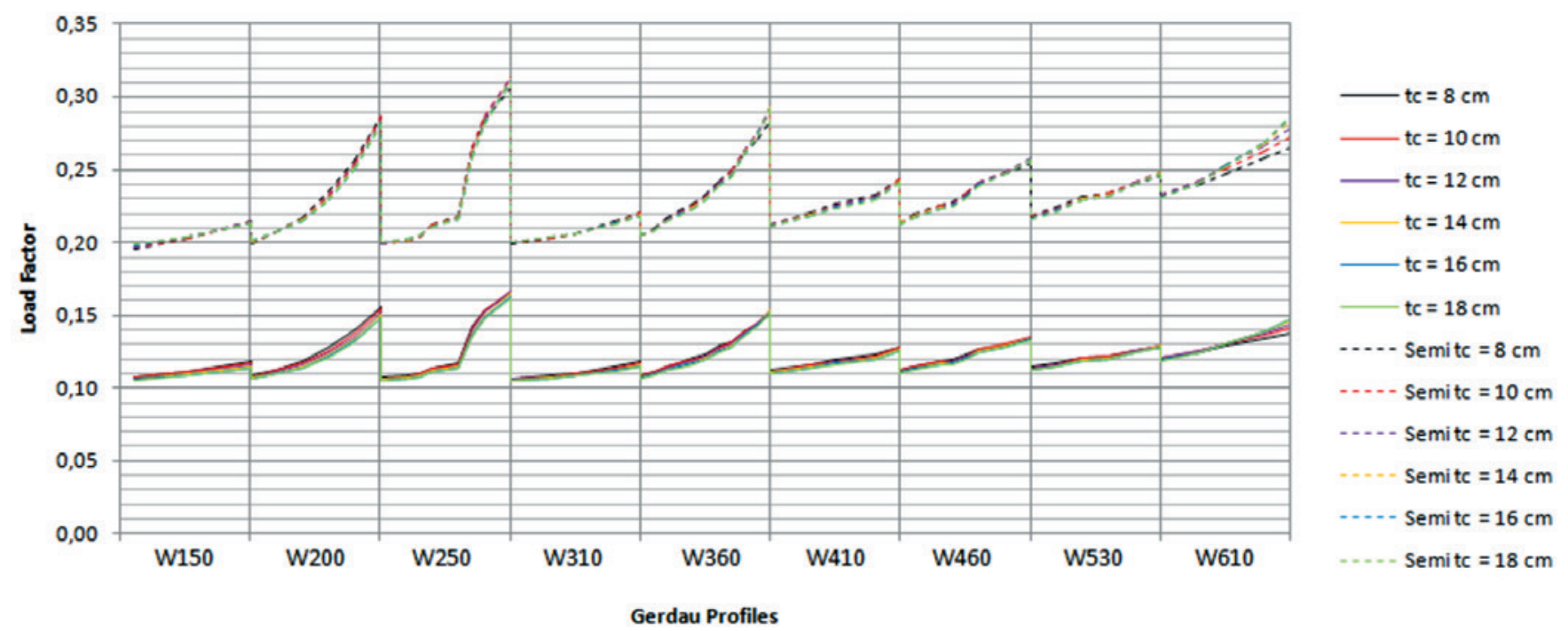

Figure 11

Load factor $x$ analyzed Gerdau profile

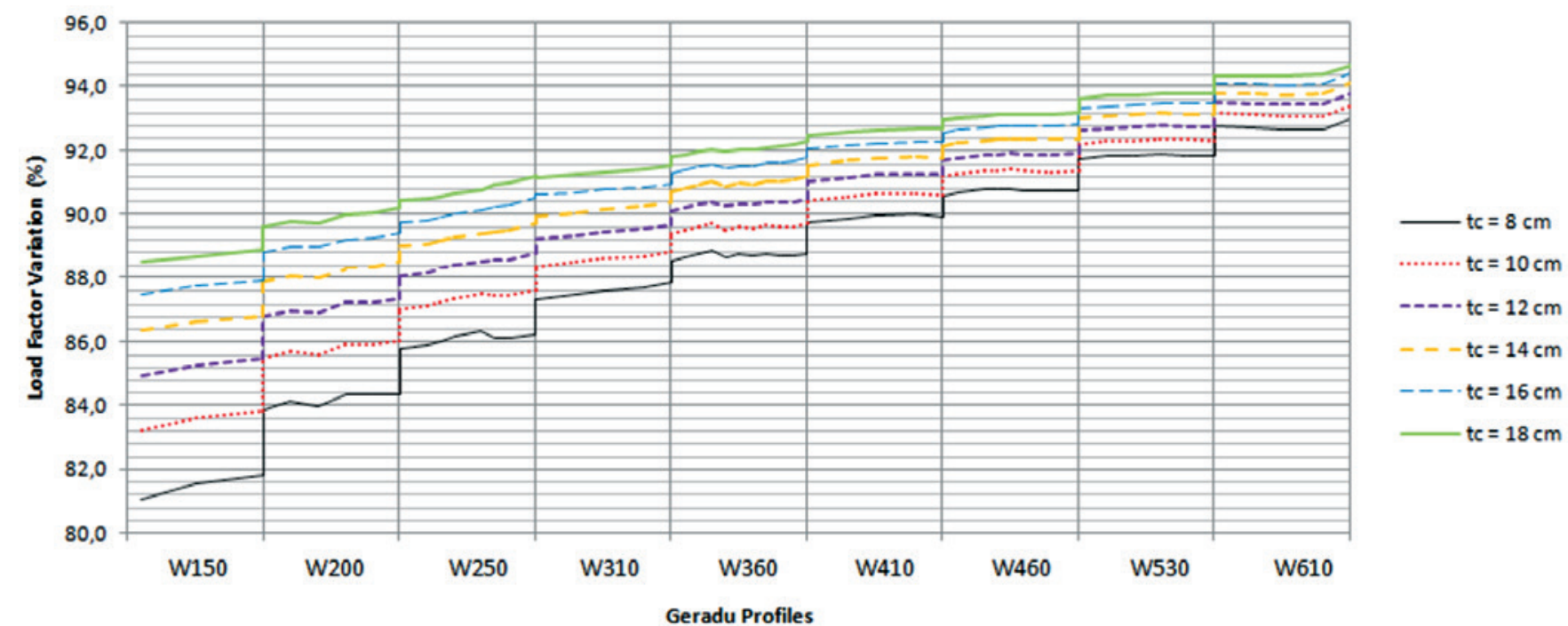

\section{Figure 12}

\section{Load factor variation x analyzed Gerdau profile}

Note that composite beams with heavier steel profiles in combination with small thickness slabs require higher reinforcement ratios, reaching a maximum value of $1.20 \%$. The values ranged, on average, from $0.18 \%$ for the $18 \mathrm{~cm}$ slab to $0.41 \%$ for the $8 \mathrm{~cm}$ slab, which means approximately a reinforcement steel cross section area of $3.2 \mathrm{~cm}^{2} / \mathrm{m}$ of slab.

In Figure 11 we find the load factor, Equation (38), for each case assuming the maximum possible reinforcement ratios. The filled lines indicate the fire situation analysis for the simply supported cases and the dashed lines for the semi-continuous beam. It can be seen that the variation of the slab thickness has little effect on the results, for each profile series.

The graphic of Figure 12 indicates the load factor variation be- tween the simply supported and semi-continuous models in fire. In the presented scale it is possible to notice that the slab's thickness has more influence for shorter profiles, but the variation is small, on the $8 \%$ order at best.

Although the semi-continuous alternative increases from $80 \%$ to $95 \%$ the resistance of the composite beam in fire situation, the load factor reaches 0.31 at best, with an average of 0.23 .

As a comparison, ABNT NBR 14323 [1] allows, for simplicity, the use of a 0.70 load factor, in terms of internal forces, for the fire ultimate limit state design. A load factor of 0.30 would only be relevant for a building in which live loads were much higher than dead loads, with unusual values. That is, the simply supported or semi-continuous analyzed beams would not support the 30 minute 
standard fire resistance requirement without fireproof coatings. This work was developed for a 30 min standard fire requirement resistance and will serve as a basis for future analyzes of lesser values. Although rare, standard fire requirement resistances lower than 30 min may occur when using the time equivalence method $[16,17]$.

\section{Conclusions}

It was carried out a study of composite steel and concrete beams behavior in fire considering the rotational stiffness in the supports provided by the negative longitudinal slab reinforcement and restriction of the steel profile lower flange. Generally, composite beams are designed at room temperature as simply supported and the semi-continuity provided by such longitudinal reinforcement, if considered in fire situation, may lead to a lower cost solution for fire protection of composite beams.

From the results presented by the simplified analysis we can conclude:

- Usual slabs anti-cracking meshes reinforcement ratio values are enough to guarantee the maximum negative bending moment capacity of the composite beam so that the only additional action needed to consider the semi-continuity is the restriction of the steel profile lower flange at the support;

- For the 30 minutes standard fire resistance requirement, although there is a significant increase in strength of the semicontinuous beam compared to a simply supported situation, this increase is not enough to dispense fireproof coatings;

- It is still necessary to analyze standard fire resistance requirements lower than 30 minutes that, although rare, may occur when using the time equivalence method.

- Future work should be able to evaluate the indirect thermal stresses impact on the composite beam capacity with aid of nonlinear numerical analyses. Such analyzes will be able to include membrane effects pointed by several authors.

\section{References}

[1] ASSOCIAÇÃO BRASILEIRA DE NORMAS TÉCNICAS. NBR 14323: Projeto de estruturas de aço e de estruturas mistas de aço e concreto de edifícios em situação de incêndio. Rio de Janeiro, 2013.

[2] USMANI, A. S.; ROTTER, J. M.; LAMONT, S.; SANAD A. M.; GILLIE M. Fundamental principles of structural behaviour under thermal effects. Fire Safety Journal, v.36, p. 721-744. Elsevier, 2001.

[3] USMANI, A. S.; ROTTER, J. M.; GILLIE M. A structural analysis of the first Cardington test. Journal of Constructional Steel Research, v.57, p. 581-601. Elsevier, 2001.

[4] KODUR V. K. R.; NASER M.; PAKALA P.; VARMA A. Modeling the response of composite beam-slab assemblies exposed to fire. Journal of Constructional Steel Research, v.80, p. 163-173. Elsevier, 2013.

[5] HUANG Z.; LIN S.; FAN M. The effects of protected beams and their connections on the fire resistance of composite buildings. Fire Safety Journal, v.78, p. 31-43. Elsevier, 2015.

[6] WANG Y.; SWAILES T.; MARAVEAS C. A detailed methodology for the finite element analysis of asymmetric slim floor beams in fire. Steel Construction, v.5, no. 3. Ernst \& Sohn: Berlin, 2012.

[7] CHIOU Y. J.; LIEN K. H.; WANG R. Z.; HSIAO P. A. Nonlinear behaviour of steel structures considering the cooling phase of a fire. Journal of Constructional Steel Research, v.65, p.1776-1786. Elsevier, 2009.

[8] KODUR V. K. R.; NASER M. Z. Effect of local instability on capacity of steel beams exposed to fire. Journal of Constructional Steel Research, v.111, p.31-42. Elsevier, 2015.

[9] NGUYEN T. T.; TAN K. H. Experimental and numerical evaluation of composite floor systems under fire conditions. Journal of Constructional Steel Research, v.105, p.86-96. Elsevier, 2015.

[10] IOANNIDES S. A.; MEHTA S. Restrained versus unrestrained fire ratings for steel structures - a practical approach. Modern Steel Construction. Chicago: AISC, 1997.

[11] FAKURY R. H.; CASAS E. B.; PACÍFICO F. F.; ABREU L. M. P. Design of semi-continuous composite steel-concrete beams at the fire limit state. Journal of Constructional Steel Research, v.61, p.1094-1107. Elsevier, 2005.

[12] FISCHER E. C.; VARMA A. H. Fire resilience of composite beams with simple connections: Parametric studies and design. Journal of Constructional Steel Research, v.128, p.119135. Elsevier, 2017.

[13] ASSOCIAÇÃO BRASILEIRA DE NORMAS TÉCNICAS. NBR 8800: Projeto de estruturas de aço e de estruturas mistas de aço e concreto de edifícios. Rio de Janeiro, 2008.

[14] ALBUQUERQUE, G. B. M. L. Dimensionamento de vigas de concreto armado em situação de incêndio. 246f. Tese (Mestrado) - Escola Politécnica da Universidade de São Paulo, São Paulo, 2012.

[15] EUROPEAN COMMITTEE FOR STANDARDIZATION.EN 1994-1-2: Eurocode 4: Design of composite steel and concrete structures - part 1-2: General rules - Structural fire design. Brussels: CEN, 2005.

[16] ASSOCIAÇÃO BRASILEIRA DE NORMAS TÉCNICAS. NBR 15200: Projeto de estruturas de concreto em situação de incêndio. Rio de Janeiro, 2012.

[17] SILVA, V. P. Projeto de Estruturas de Concreto em Situação de Incêndio. São Paulo: Editora Blucher, 2012. 